\title{
Persepsi Wisatawan Domestik dan Mancanegara terhadap Pengelolaan Daya Tarik Wisata Jatiluwih, Kabupaten Tabanan, Provinsi Bali
}

\author{
Dewa Ayu Diyah Sri Widari ${ }^{1}$
}

\author{
Affiliation \\ ${ }^{1}$ Akademi Pariwisata Denpasar
}

\section{Correspondence}

Dewa Ayu Diyah Sri Widari, Akademi Pariwisata Denpasar, Jl. Tukad Balian No.15, Renon, Denpasar Selatan, Kota Denpasar, Bali 80239, Email: dewaayusriwidari@gmail.com

\begin{abstract}
Jatiluwih Tourism Attraction as part of the World Cultural Heritage is a tourist product consumed by tourists. Perception of tourists is important to be studied as a reference in the management of tourist attractions. Data collection techniques using survey methods are used to determine tourists' perception of Jatiluwih Tourism Attraction as part of the World Cultural Heritage. Questionnaires are used as research instruments to obtain information from tourists. After the data is collected, then the measurement is done using the Likert Scale. In determining the number of tourist samples used Slovin formula. Based on Slovin formula with a tolerance limit of 5\%, the number of samples for foreign tourists as many as 204 people, and the number of samples for domestic tourists as many as 52 people. The total sample count was 256 people. Domestic and foreign tourists give the highest perception of employment opportunities for the community from the management of tourist attractions. Good perception of tourists is also given to the friendliness of the staff in providing service, naturalness, and beauty of the scenery around the tourist attraction. The perception of tourists is not good given to the price of souvenirs, ease of access to the internet, availability of souvenirs with local characteristics, and smooth traffic around tourist attractions.
\end{abstract}

Keywords: Peception; management; tourist attraction; Jatiluwih

Article Information:

Submitted 13 July 2021|Revised 13 July 2021|Accepted 26 July 2021

Copyright (C) 2021 by the author(s). This article is published by Universitas Gadjah Mada, Indonesia under the Creative Commons Attribution (CC BY 4.0) license. Anyone may reproduce, distribute, translate, and create derivative works of this article (for both commercial and noncommercial purposes), subject to full attribution to the original publication and author(s). The full terms of this license may be seen at

http://creativecommons.org/licenses/by/4.0/legalcod 


\section{Pendahuluan}

Penetapan Lanskap Budaya Provinsi Bali sebagai Warisan Budaya Dunia pada Keputusan Sidang ke-36 Komite Warisan Dunia karena subak memiliki nilai luar biasa yang bersifat universal (outstanding universal value) yang mencakup tiga hal yaitu pertama, memiliki keunikan atau pengakuan luar biasa terhadap tradisi budaya atau peradaban yang masih berlaku (unique testimonies to cultural traditions/civilisations). Kedua, merupakan contoh luar biasa tentang pemukiman tradisional manusia dan tata guna tanah (traditional human settlement, land use, or sea use). Ketiga, peristiwa atau tradisi yang berlaku dengan gagasan atau dengan keyakinan yang memiliki nilai universal luar biasa dan secara langsung membentuk suatu lansekap (association with events or living traditions).

Dalam penetapan Lanskap Budaya Bali, Subak Jatiluwih merupakan salah satu subak yang ditetapkan sebagai bagian dari Warisan Budaya Dunia. Desa Jatiluwih berlokasi di Kecamatan Penebel, Kabupaten Tabanan. Desa ini memiliki panorama alam yang indah dengan keunikan sawah yang berundak-undak. Dengan keunikan terasering sawah yang dimiliki, subak yang merupakan organisasi petani pada sawah di Desa Jatiluwih dijadikan sebagai daya tarik wisata utama. Keunikan terasering sawah juga didukung oleh udara yang relatif sejuk, karena berada pada ketinggian kurang lebih 1,059 meter di atas permukaan laut.

Subak ditetapkan sebagai bagian dari Warisan Budaya Dunia melalui proses yang panjang. Dimulai dari tahun 2000, subak di Bali diusulkan untuk menjadi Warisan Budaya Dunia. Selanjutnya, tahun 2004 dimasukkan dalam nomination list of UNESCO. Setelah menunggu selama 12 tahun, akhirnya subak ditetapkan sebagai Warisan Budaya Dunia pada tanggal 29 Juni 2012. Penetapan subak sebagai Warisan Budaya Dunia menurut UNESCO merupakan kombinasi antara alam dan hasil karya manusia, dalam perkembangannya harus memberikan manfaat bagi pelestarian alam serta keberhasilan dari aspek sosial, ekonomi, dan sumberdaya budaya (Yamashita, 2013).

Daya Tarik Wisata Jatiluwih sebagai bagian dari Warisan Budaya Dunia merupakan suatu produk wisata yang dikonsumsi oleh wisatawan. Persepsi wisatawan juga penting dikaji sebagai acuan dalam pengelolaan daya tarik wisata. Sesuai dengan pernyataan Vong (2013) bahwa persepsi terhadap interpretasi kualitas warisan budaya secara signifikan berkaitan dengan image destinasi budaya dan kepuasan untuk mengunjungi situs. Selain itu Teo, dkk. (2014) menyatakan bahwa indikator kepuasan wisatawan bisa digunakan untuk menarik calon wisatawan ke destinasi dan untuk memastikan mereka kembali mengunjungi destinasi. Penelitian oleh Wiranatha dan Suryawardani (2016) menyatakan bahwa dari sisi produk, terbatasnya informasi bagi wisatawan tentang keunikan sistem subak yang bisa diakses oleh wisatawan. Terkait dengan hal tersebut, wisatawan sebagai konsumen perlu disediakan fasilitas dan pelayanan yang memuaskan, termasuk dalam penyediaan informasi yang jelas dan akurat. Dari penyediaan fasilitas dan pelayanan, wisatawan akan memberikan berbagai respons atau penilaian yang dapat dijadikan sebagai bahan evaluasi untuk pengelolaan daya tarik wisata yang berkelanjutan. 


\section{Metode}

Teknik pengumpulan data menggunakan metode survei dipakai untuk mengetahui persepsi wisatawan terhadap Daya Tarik Wisata Jatiluwih sebagai bagian dari Warisan Budaya Dunia. Kuesioner dipergunakan sebagai instrumen penelitian untuk memperoleh informasi dari wisatawan. Setelah data/informasi dikumpulkan, selanjutnya pengukuran dilakukan dengan mempergunakan Skala Likert.

Dalam menentukan jumlah sampel wisatawan dipergunakan Rumus Slovin. Menurut Slovin (1960) untuk menggunakan rumus ini, pertama ditentukan batas toleransi kesalahan yang dinyatakan dengan persentase. Batas toleransi yaitu 5\%, 10\%, dan 15\%. Berdasarkan Rumus Slovin dengan batas toleransi $5 \%$, maka jumlah sampel untuk wisatawan mancanegara sebanyak 204 orang, dan jumlah sampel untuk wisatawan domestik sebanyak 52 orang. Jumlah sampel keseluruhan sebanyak 256 orang.

\section{Hasil dan Pembahasan}

Dalam penelitian ini telah berpartisipasi sebanyak 256 responden, yang terdiri dari 52 responden wisatawan domestik dan 204 responden wisatawan mancanegara. Semua item pertanyaan pada kuesioner telah diisi dengan baik oleh responden, sehingga seluruh data pada kuesioner dapat dianalisis. Penyebaran kuesioner berisi komponen/indikator pernyataan yang mencerminkan aspek ekonomi, aspek sosial budaya, serta aspek lingkungan. Aspek ekonomi terdiri dari sembilan komponen pernyataan tentang tarif tiket masuk, harga makanan dan minuman, harga paket trekking, harga penyewaan sepeda, tarif tiket parkir, harga cinderamata, tarif jasa pemandu lokal, kesempatan kerja bagi masyarakat, dan keberadaan fasilitas ATM di daya tarik wisata. Aspek sosial budaya terdiri dari 14 komponen pernyataan tentang keramahtamahan staf dalam memberikan pelayanan, informasi tentang subak beserta aktivitasnya, kesediaan staf untuk membantu, keramahtamahan masyarakat lokal, ketersediaan penunjuk jalan, fasilitas internet, ketersediaan cinderamata berciri khas lokal, kuliner berciri khas lokal, keamanan dan kenyamanan selama di daya tarik wisata, pengalaman baru yang bersifat tradisional, aksessibilitas, atraksi budaya pertanian, pengelolaan atraksi budaya, dan lokasi daya tarik wisata. Aspek lingkungan terdiri dari 11 komponen pernyataan tentang kealamian dan keindahan pemandangan di sekitar daya tarik wisata, kondisi udara di daya tarik wisata, keberadaan fasilitas berupa toilet, kebersihan toilet, ketersediaan tempat parkir, kondisi lalu lintas di sekitar daya tarik wisata, kondisi air di sungai dan parit, ketersediaan tempat sampah, kebersihan daya tarik wisata, keasrian tanaman di sekitar daya tarik wisata, dan arsitektur tradisional Bali pada bangunan di sekitar daya tarik wisata. Komponen-komponen dirumuskan berdasarkan Buku Panduan Tri Hita Karana Awards and Accreditation (Wardana, 2018:25-37), Seyidov dan Adomaitiene (2016), dan Teo dkk. (2014).

\section{Karakteristik Wisatawan Domestik dan Wisatawan Mancanegara}

Hasil analisis berdasarkan kategori wisatawan menunjukkan karakteristik dan persepsi masingmasing wisatawan yang berkunjung ke Daya Tarik Wisata Jatiluwih. Untuk menganalisis mengenai perbedaan dan persamaan antara wisatawan domestik dan wisatawan mancanegara dilakukan perbandingan berdasarkan karakteristik dan persepsi wisatawan. 
Berdasarkan jenis kelamin, mayoritas wisatawan yang berkunjung ke Daya Tarik Wisata Jatiluwih adalah laki-laki. Wisatawan domestik sebanyak 55,76\% berjenis kelamin laki-laki dan 44,24\% berjenis kelamin perempuan. Wisatawan mancanegara dengan jenis kelamin laki-laki sebanyak $56,37 \%$ dan jenis kelamin perempuan sebanyak 43,73\%. Dilihat dari umur, wisatawan domestik yang berkunjung berumur antara 19-70 tahun, dari kisaran usia wisatawan tersebut sebanyak $71,15 \%$ sudah berkeluarga. Usia wisatawan mancanegara yang berwisata ke Daya Tarik Wisata Jatiluwih berkisar antara 18-67 tahun, dari kisaran usia tersebut sebanyak $71,08 \%$ sudah berkeluarga. Berdasarkan jumlah kunjungan ke Daya Tarik Wisata Jatiluwih, mayoritas wisatawan pertama kali melakukan kunjungan. Wisatawan domestik yang melakukan kunjungan pertama kali sebanyak 48,08\%, sedangkan wisatawan mancanegara sebanyak 94,12\%.

Selama berwisata ke Daya Tarik Wisata Jatiluwih, mayoritas wisatawan domestik yaitu 76,92\% ditemani oleh keluarganya, tidak ada wisatawan yang melakukan perjalanan seorang diri, mendukung penelitian Seyidov dan Adomeitiene (2016). Wisatawan mancanegara mayoritas berkunjung ke Daya Tarik Wisata Jatiluwih seorang diri atau tidak ada yang menemani yaitu sebanyak 35\%. Berdasarkan sumber informasi, wisatawan domestik yang berkunjung ke Daya Tarik Wisata Jatiluwih mayoritas memperoleh informasi dari keluarga yaitu sebanyak 65,38\%. Berbeda dengan penelitian Jaafar dkk. (2014), wisatawan domestik memperoleh informasi dari media cetak, sedangkan Seyidov dan Adomeitiene (2016) media internet dan teman sebagai sumber informasi yang dipercaya oleh wisatawan domestik. Wisatawan mancanegara mayoritas memperoleh sumber informasi dari internet yaitu sebanyak 49,51\%, mendukung penelitian Jaafar dkk. (2014). Mayoritas wisatawan domestik berkunjung karena tertarik akan alam dan budaya yaitu sebanyak $42,31 \%$, sedangkan wisatawan mancanegara mayoritas tertarik akan alam, budaya, dan minat khusus yaitu sebanyak 28,05\%. Seluruh wisatawan domestik dan mancanegara bersedia merekomendasikan kepada teman atau keluarga mereka untuk menjadikan Daya Tarik Wisata Jatiluwih sebagai pilihan berwisata.

\section{Persepsi Wisatawan Domestik dan Wisatawan Mancanegara Terhadap Aspek Ekonomi}

Persepsi wisatawan terhadap aspek ekonomi dilihat dari sembilan komponen antara lain tentang tarif tiket masuk, harga makanan dan minuman, harga paket trekking, harga penyewaan sepeda, tarif tiket parkir, harga cinderamata, tarif jasa pemandu lokal, kesempatan kerja bagi masyarakat, dan keberadaan fasilitas ATM di daya tarik wisata. Persepsi wisatawan dari aspek ekonomi berkaitan dengan atribut kualitas layanan dan kepuasan. Kedua atribut ini akan membentuk dan mempengaruhi persepsi wisatawan terhadap Daya Tarik Wisata Jatiluwih dari aspek ekonomi. Persepsi dari aspek ekonomi berbeda-beda, menurut Sarwono (2003:242) hal ini terjadi karena persepsi merupakan penafsiran yang unik terhadap sebuah situasi.

Berdasarkan penelitian diperoleh hasil bahwa persepsi wisatawan domestik dan wisatawan mancanegara terhadap sembilan komponen pada aspek ekonomi terdapat perbedaan. Rata-rata skor penilaian terhadap aspek ekonomi oleh wisatawan domestik sebesar 4,71 sedangkan untuk wisatawan mancanegara sebesar 3,92. Dengan demikian rata-rata skor kesembilan aspek ekonomi sebesar 4,31. Mengacu pada Sarwono (2003:242) dan Parasuraman dkk. (1985) perbedaan persepsi sangat dimungkinkan sebagai akibat perbedaan dalam penafsiran situasi terutama mengenai kualitas pelayanan yang diharapkan dan dirasakan. 
Jika rata-rata skor kesembilan aspek ekonomi dibandingkan dengan rata-rata skor tiap komponen dari aspek ekonomi, terdapat empat komponen yang rata-rata skornya di bawah 4,31 dan lima komponen yang rata-rata skornya di atas 4,31. Adapun empat komponen aspek ekonomi yang skornya di bawah rata-rata adalah harga paket trekking (skor 4,29), tarif tiket parkir (skor 4,28), harga penyewaan sepeda (skor 4,26), dan harga cinderamata (skor 4,24). Sedangkan lima komponen aspek ekonomi yang skornya di atas rata-rata adalah kesempatan kerja dari pengelolaan daya tarik wisata (skor 4,39), tarif tiket masuk (skor 4,37), tarif jasa pemandu lokal (skor 4,35), harga makanan dan minuman (skor 4,33), dan fasilitas ATM (skor 4,32). Secara terperinci persepsi terhadap aspek ekonomi dari wisatawan domestik dan wisatawan mancanegara seperti Tabel 1.

Tabel 1. Persepsi Wisatawan Domestik dan Mancanegara Terhadap Aspek Ekonomi

\begin{tabular}{lllll}
\hline \multirow{2}{*}{ No } & Komponen Penilaian Aspek Ekonomi & \multicolumn{2}{c}{ Total Skor } & \multirow{2}{*}{$\begin{array}{l}\text { Rata-rata } \\
\text { Komponen }\end{array}$} \\
\cline { 3 - 4 } & & $\begin{array}{l}\text { Wisatawan } \\
\text { Domestik }\end{array}$ & $\begin{array}{l}\text { Wisatawan } \\
\text { Mancanegara }\end{array}$ \\
\hline 1 & Tarif tiket masuk wajar & 4,69 & 4,05 & 4,37 \\
2 & Harga makanan dan minuman terjangkau & 4,67 & 3,99 & 4,33 \\
3 & Harga paket trekking wajar & 4,61 & 3,97 & 4,29 \\
4 & Harga penyewaan sepeda wajar & 4,69 & 3,84 & 4,26 \\
5 & Tarif tiket parkir wajar & 4,67 & 3,89 & 4,28 \\
6 & Harga cinderamata terjangkau & 4,69 & 3,80 & 4,24 \\
7 & Tarif jasa pemandu lokal wajar & 4,83 & 3,88 & 4,35 \\
8 & Pengelolaan daya tarik wisata memberi & 4,79 & 3,99 & 4,39 \\
& kesempatan kerja & & & 4,32 \\
9 & Tersedia fasilitas ATM yang memadai & 4,79 & 3,86 & 4.31 \\
\hline & Rata-rata Skor Aspek & 4,71 & 3,92 & \\
\hline
\end{tabular}

Sumber: Data Primer Diolah, 2018

Komponen aspek ekonomi yang memperoleh skor tertinggi adalah kesempatan kerja yang ditimbulkan dari pengelolaan daya tarik wisata dengan skor 4,39, wisatawan menilai bahwa pengelolaan Daya Tarik Wisata Jatiluwih mampu menyerap tenaga kerja. Wisatawan memberikan penilaian seperti ini berdasarkan dari pelayanan yang didapatkan pada saat memasuki pintu gerbang wisatawan, pengecekan tiket, pelayanan pengaturan arus lalu lintas wisatawan, pelayanan informasi oleh pemandu wisata, dan pelayanan pada usaha restoran, warung makan, dan stand kuliner. Hal ini menunjukkan bahwa wisatawan memberi apresiasi tinggi terhadap penyerapan tenaga kerja dalam pengelolaan daya tarik wisata, sesuai dengan Jafari (2001) bahwa persepsi wisatawan berkaitan dengan pengelolaan pariwisata yang berpengaruh terhadap ekonomi lokal, dapat mempengaruhi niat untuk berkunjung kembali. Sehingga diperlukan program-program untuk lebih mengoptimalkan penyerapan tenaga kerja dalam pengelolaan Daya Tarik Wisata Jatiluwih sebagai upaya untuk mencapai ekonomi yang berkelanjutan.

Persepsi terhadap aspek ekonomi yang memperoleh skor terendah adalah harga cinderamata dengan skor 4,24. Penilaian ini berarti bahwa wisatawan domestik dan mancanegara memberi 
apresiasi kurang terhadap harga dari cinderamata yang ditawarkan. Hal ini sesuai dengan pernyataan Dzulkifli dan Masjhoer (2020) bahwa harga cinderamata di destinasi wisata merupakan salah satu faktor yang berpengaruh terhadap tingkat kepuasan wisatawan yang berkunjung. Kurangnya ketersediaan toko yang menjual cinderamata khas Jatiluwih mendukung penelitian Perera dkk., (2014) dan terbatasnya produk cinderamata yang dijual memberi implikasi pada harga jual yang ditetapkan.

\section{Persepsi Terhadap Aspek Sosial Budaya}

Rata-rata skor penilaian terhadap aspek sosial budaya oleh wisatawan domestik sebesar 4,85 sedangkan wisatawan mancanegara sebesar 4,03. Rata-rata skor 14 aspek sosial budaya sebesar 4,44 . Apabila rata-rata skor dari aspek sosial budaya dibandingkan dengan rata-rata skor tiap komponen dari aspek sosial budaya, terdapat delapan komponen yang rata-rata skornya di atas atau sama dengan $4,44(>/ 4,44)$ dan enam komponen yang rata-rata skornya di bawah 4,44 $(<4,44)$.

Komponen aspek sosial budaya yang skornya lebih besar atau sama dengan rata-rata $(>/ 4,44)$ adalah pelayanan staf (skor 4,56), informasi tentang subak dan aktivitasnya (skor 4,53), ketersediaan staf untuk membantu (skor 4,50), pengalaman baru yang bersifat tradisional (skor 4,48), aksessibilitas menuju lokasi (skor 4,46), atraksi budaya pertanian (skor 4,45), keramahtamahan masyarakat lokal (skor 4,44), dan pengelolaan atraksi budaya pertanian (skor $4,44)$. Sedangkan 6 komponen yang skornya lebih kecil dari rata-rata $(<4,44)$ adalah lokasi daya tarik wisata (skor 4,43), ketersediaan penunjuk arah (skor 4,41), kuliner dengan ciri khas lokal (skor 4,39), keamanan dan kenyamanan selama berkunjung ke daya tarik wisata (skor 4,39), kemudahan mengakses internet (skor 4,32), dan cinderamata berciri khas lokal (skor 4,32), seperti yang disajikan pada Tabel 2

Tabel 2.Persepsi Wisatawan Domestik dan Mancanegara terhadap Aspek Sosial Budaya

\begin{tabular}{|c|c|c|c|c|}
\hline \multirow[b]{2}{*}{ No } & \multirow[b]{2}{*}{ Komponen Penilaian Aspek Sosial Budaya } & \multicolumn{2}{|l|}{ Total Skor } & \multirow{2}{*}{$\begin{array}{l}\text { Rata-rata } \\
\text { onen }\end{array}$} \\
\hline & & $\begin{array}{l}\text { Wisatawa } \\
\mathrm{n} \\
\text { Domestik }\end{array}$ & $\begin{array}{l}\text { Wisatawan } \\
\text { Mancanegar } \\
\text { a }\end{array}$ & \\
\hline 1 & Pelayanan staf baik dan ramah & 4,90 & 4,23 & 4,56 \\
\hline 2 & $\begin{array}{l}\text { Memperoleh informasi tentang subak } \\
\text { beserta aktivitasnya }\end{array}$ & 4,90 & 4,17 & 4,53 \\
\hline 3 & Staf bersedia membantu & 4,85 & 4,15 & 4,50 \\
\hline 4 & Masyarakat lokal bersikap ramah & 4,79 & 4,09 & 4,44 \\
\hline 5 & Penunjuk jalan tersedia dan mudah dilihat & 4,85 & 3,97 & 4,41 \\
\hline 6 & Fasilitas internet mudah diakses & 4,85 & 3,79 & 4,32 \\
\hline 7 & Tersedia cinderamata berciri khas lokal & 4,83 & 3,82 & 4,32 \\
\hline 8 & Tersedia kuliner berciri khas lokal & 4,86 & 3,93 & 4,39 \\
\hline 9 & $\begin{array}{l}\text { Merasa aman dan nyaman selama } \\
\text { berkunjung }\end{array}$ & 4,69 & 4,09 & 4,39 \\
\hline 10 & Memperoleh pengalaman baru & 4,90 & 4,06 & 4,48 \\
\hline 11 & Aksessibilitas menuju lokasi baik & 4,88 & 4,04 & 4,46 \\
\hline 12 & Atraksi budaya pertanian menarik & 4,88 & 4,02 & 4,45 \\
\hline
\end{tabular}




\begin{tabular}{|c|c|c|c|c|}
\hline 13 & $\begin{array}{l}\text { Atraksi budaya pertanian dikelola dengan } \\
\text { baik }\end{array}$ & 4,88 & 4,01 & 4,44 \\
\hline 14 & $\begin{array}{l}\text { Lokasi daya tarik wisata berada pada posisi } \\
\text { utama }\end{array}$ & 4,85 & 4,01 & 4,43 \\
\hline & Rata-rata Skor Aspek & 4,85 & 4,03 & 4,44 \\
\hline & Rata-rata & 4,44 & & \\
\hline
\end{tabular}

Sumber: Data Primer Diolah, 2018

Berdasarkan Tabel 2 terlihat bahwa kemudahan untuk mengakses internet di Daya Tarik Wisata Jatiluwih memperoleh skor terendah yaitu 4,32 artinya wisatawan domestik dan wisatawan mancanegara tidak puas dengan akses internet di daya tarik wisata. Ekspresi kreatifitas di Daya Tarik Wisata Jatiluwih antara lain berupa ketersediaan kuliner dengan ciri khas lokal serta ketersediaan cinderamata dengan ciri khas lokal. Khusus untuk cinderamata dengan ciri khas lokal, berdasarkan persepsi wisatawan memperoleh skor terendah yaitu 4,32. Ini berarti meskipun cinderamata lokal sudah tersedia namun ketersediaannya masih terbatas, masih perlu dilakukan perbaikan dari sisi produk serta kemasan untuk meningkatkan kepuasan wisatawan atau dengan melakukan diversifikasi produk. Hal ini juga sesuai dengan hasil penelitian Dzulkifli dan Masjhoer (2020).

Persepsi wisatawan terhadap keramahtamahan staf memperoleh skor tertinggi yaitu 4,56 yang berarti wisatawan domestik dan mancanegara sangat puas dengan keramahtamahan staf dalam memberikan pelayanan. Hal yang berbeda ditemukan oleh Perera (2014) bahwa keramahtamahan staf dan bantuan pramuwisata kurang mendukung dalam pemberian pelayanan. Manajemen Operasional Daya Tarik Wisata Jatiluwih telah menetapkan Standar Operasional Prosedur (SOP) dalam memberikan pelayanan kepada wisatawan. Karyawan yang bertugas melayani wisatawan pada pos retribusi, pos pengecekan tiket masuk, maupun pada pondok informasi wajib melaksanakan prosedur kerja.

Pengalaman baru yang bersifat tradisional, keamanan, dan kenyamanan selama berkunjung ke daya tarik wisata juga menjadi komponen aspek sosial budaya yang dinilai oleh wisatawan. Hasil penelitian menunjukkan bahwa wisatawan merasa puas dengan pengalaman baru yang disuguhkan oleh Daya Tarik Wisata Jatiluwih yang merupakan bagian dari Warisan Budaya Dunia. Menikmati dan menyusuri keindahan hamparan terasering persawahan yang terbentang luas merupakan pengalaman baru bagi wisatawan. Sedangkan untuk komponen keamanan dan kenyamanan, wisatawan menilai kurang puas sesuai dengan penelitian Perera dkk. (2014). Hal ini terjadi karena pada jalur yang sering digunakan wisatawan selama berada di Daya Tarik Wisata Jatiluwih, selain dipergunakan untuk wisatawan juga dipergunakan oleh masyarakat lokal menjalankan aktivitas pertanian. Alat transportasi yang dipergunakan tidak saja kendaraan roda dua akan tetapi juga kendaraan roda empat. Kondisi inilah yang membuat wisatawan merasa tidak aman dan tidak nyaman.

Informasi tentang subak dan aktivitasnya, atraksi budaya pertanian, dan pengelolaan atraksi budaya pertanian juga menjadi fokus penilaian wisatawan. Berdasarkan Hasil penelitian, wisatawan merasa puas dengan disediakannya Pondok Informasi pada jalur trekking di wilayah Tempek Telabah Gede. Mendukung penelitian Khlaikaew (2015) bahwa tersedia informasi yang 
cukup dan baik mengenai sumberdaya sejarah dari pemandu lokal. Sejalan dengan pernyataan Gee dan Fayos-Sola (1999) bahwa untuk pengelolaan yang berkelanjutan, daya tarik wisata harus berkualitas (quality) secara fisik serta dapat memberikan informasi yang akurat dan menarik bagi wisatawan.

Penilaian wisatawan domestik dan wisatawan mancanegara terhadap aksessibilitas menuju lokasi sudah baik, namun ketersediaan penunjuk arah dan lokasi daya tarik wisata berada pada posisi utama dan mudah dilihat dinilai masih kurang. Beberapa petunjuk arah sudah dipasang pada jalur menuju Jatiluwih namun perlu ditambah dan posisinya agar mudah dilihat oleh wisatawan. Pada era digital untuk menuju suatu lokasi dapat diakses melalui google map, tetapi ketersediaan petunjuk arah tetap diperlukan karena wisatawan yang berkunjung ada yang tidak memakai jasa travel agent. Apalagi lokasi daya tarik wisata yang berada di daerah pegunungan, pada lokasi tertentu sulit untuk mengakses internet. Terkait dengan strategi, Ratman (2016) menyebutkan ketersediaan penunjuk arah-papan informasi wisata-rambu lalu lintas sebagai bagian dari indikator prasarana umum, fasilitas umum dan pariwisata yang merupakan salah satu strategi dalam pengembangan destinasi pariwisata.

Persepsi wisatawan domestik dan wisatawan mancanegara terhadap lokasi daya tarik wisata berada pada posisi utama dan mudah dilihat mendapat penilaian kurang atau tidak puas. Penilaian ini disebabkan karena untuk menikmati pemandangan yang terbaik dari terasering sawah yang menjadi view utama, wisatawan masih perlu berjalan kaki menuju lokasi. Kalau hanya menikmati view di sekitar tempat parkir kendaraan akan memperoleh pemandangan yang kurang menarik. Selain itu, luasnya terasering sawah yang menjadi daya tarik membuat wisatawan harus berjalan cukup jauh apabila ingin mendapatkan view yang bagus.

\section{Persepsi terhadap aspek lingkungan}

Rata-rata skor penilaian terhadap aspek lingkungan oleh wisatawan domestik sebesar 4,85 sedangkan wisatawan mancanegara sebesar 4,04. Rata-rata skor sebelas aspek lingkungan sebesar 4,44. Apabila rata-rata skor 11 aspek lingkungan dibandingkan dengan rata-rata skor tiap komponen dari aspek lingkungan, terdapat dua komponen yang rata-rata skornya di atas 4,44 dan sembilan komponen yang rata-rata skornya di bawah 4,44.

Komponen aspek lingkungan yang skornya lebih besar dari rata-rata skor aspek lingkungan adalah kealamian dan keindahan pemandangan di sekitar daya tarik wisata (skor 4,62) dan kesejukan udara di sekitar daya tarik wisata (skor 4,57). Sedangkan 9 komponen aspek lingkungan yang memperoleh skor lebih kecil dari rata-rata adalah kebersihan daya tarik wisata (skor 4,43 ), ketersediaan tempat parkir (skor 4,42), kondisi air sungai dan air parit (skor 4,42), ketersediaan fasilitas toilet (skor 4,41), kebersihan fasilitas toilet (skor 4,41), cerminan arsitektur lokal pada bangunan di sekitar daya tarik wisata (skor 4,41), keasrian tanaman di sekitar daya tarik wisata (skor 4,40), ketersediaan tempat sampah (skor 4,38), dan lalu lintas di sekitar daya tarik wisata (skor 4,37). Secara terperinci penilaian aspek lingkungan wisatawan domestik dan wisatawan mancanegara seperti Tabel 3. 
Tabel 3 Persepsi Wisatawan Domestik dan Mancanegara terhadap Aspek Lingkungan

\begin{tabular}{|c|c|c|c|c|}
\hline \multirow[b]{2}{*}{ No } & \multirow[b]{2}{*}{ Komponen Penilaian Aspek Lingkungan } & \multicolumn{2}{|l|}{ Total Skor } & \multirow{2}{*}{$\begin{array}{l}\text { Rata-rata } \\
\text { Komponen }\end{array}$} \\
\hline & & $\begin{array}{l}\text { Wisatawan } \\
\text { Domestik }\end{array}$ & $\begin{array}{l}\text { Wisatawan } \\
\text { Mancanegara }\end{array}$ & \\
\hline 1 & $\begin{array}{l}\text { Pemandangan di sekitar daya tarik } \\
\text { wisata masih alami dan indah }\end{array}$ & 5,0 & 4,25 & 4,62 \\
\hline 2 & $\begin{array}{l}\text { Udara sekitar daya tarik wisata masih } \\
\text { sejuk }\end{array}$ & 4,92 & 4,22 & 4,57 \\
\hline 3 & Tersedia fasilitas toilet yang cukup & 4,75 & 4,08 & 4,41 \\
\hline 4 & Fasilitas toilet terjaga kebersihannya & 4,81 & 4,02 & 4,41 \\
\hline 5 & Tersedia tempat parkir yang luas & 4,88 & 3,97 & 4,42 \\
\hline 6 & $\begin{array}{l}\text { Lalu lintas sekitar daya tarik wisata } \\
\text { lancar }\end{array}$ & 4,86 & 3,89 & 4,37 \\
\hline 7 & $\begin{array}{l}\text { Kondisi air (sungai dan parit) masih } \\
\text { jernih }\end{array}$ & 4,90 & 3,95 & 4,42 \\
\hline 8 & Tersedia tempat sampah yang cukup & 4,79 & 3,97 & 4,38 \\
\hline 9 & $\begin{array}{l}\text { Kebersihan daya tarik wisata terjaga } \\
\text { dengan baik }\end{array}$ & 4,86 & 4,01 & 4,43 \\
\hline 10 & $\begin{array}{l}\text { Tanaman sekitar daya tarik wisata } \\
\text { terjaga keasriannya }\end{array}$ & 4,75 & 4,06 & 4,40 \\
\hline \multirow[t]{3}{*}{11} & $\begin{array}{l}\text { Bangunan di sekitar lokasi daya tarik } \\
\text { wisata mencerminkan arsitektur } \\
\text { tradisional Bali }\end{array}$ & 4,83 & 3,99 & 4,41 \\
\hline & $\begin{array}{l}\text { Rata-rata Skor } \\
\text { Aspek }\end{array}$ & 4,85 & 4,04 & 4,44 \\
\hline & Rata-rata & 4,44 & & \\
\hline
\end{tabular}

Sumber: Data Primer Diolah, 2018

Kealamian dan keindahan pemandangan di sekitar daya tarik wisata memperoleh rata-rata skor tertinggi yaitu 4,62. Hal ini berarti wisatawan domestik dan mancanegara menilai pemandangan alam di daya tarik wisata serta wilayah di sekitarnya masih sangat baik dan alami. Keindahan dan kesejukan udara di daya tarik wisata didukung oleh keasrian tanaman yang ada di sekitar daya tarik wisata juga dinilai sangat baik dengan skor 4,40.

Kebersihan daya tarik wisata dinilai sangat baik (skor 4,43 ) serta fasilitas dan kebersihan toilet juga dinilai sangat baik yaitu masing-masing dengan skor 4,41. Toilet dan areal di sekitar Daya Tarik Wisata Jatiluwih terjaga kebersihannya, terdapat petugas kebersihan yang setiap hari bertugas untuk menjaga kebersihannya.

Kelancaran lalu lintas di sekitar daya tarik wisata mendapat skor terendah yaitu 4,37. Perlu dilakukan perbaikan dan peningkatan dalam pengaturan lalu lintas di sekitar daya tarik wisata. Upaya untuk mengurangi kemacetan di sekitar daya tarik wisata yang menjadi view utama terus dilakukan oleh Manajemen Operasional Daya Tarik Wisata Jatiluwih, antara lain mengatur kendaraan yang parkir dengan kendaraan yang melintas di daya tarik wisata terutama pada waktu-waktu sibuk (antara pukul 11.00 - 14.00 Wita) serta bekerjasama dengan pemilik restoran untuk menyediakan kantong-kantong parkir. Jika terpaksa dilakukan parkir kendaraan sepanjang jalan yang menjadi view utama, maka parkir diatur satu jalur dan tidak menghalangi view utama. 
Kebersihan air di parit dan air sungai yang ada di sekitar Daya Tarik Wisata Jatiluwih memperoleh skor 4,42. Penilaian ini menunjukkan bahwa wisatawan masih percaya terhadap kebersihan air yang mengalir di parit atau sungai sekitar daya tarik wisata. Hal ini ditunjukkan dengan adanya wisatawan yang menggunakan air parit atau air sungai untuk membasuh muka atau hanya sekedar merendam kaki mereka.

Cerminan arsitektur tradisional Bali khususnya dari bangunan yang ada di sekitar Daya Tarik Wisata Jatiluwih dinilai sangat baik dengan skor 4,41. Meskipun arsitektur tradisional Bali bukan menjadi daya tarik utama dari Daya Tarik Wisata Jatiluwih, namun keberadaan arsitektur bangunan tradisional sebagai sebuah karya manusia (man made features) berpotensi sebagai sebuah daya tarik wisata. Sejalan dengan Kierchhoff (1997), Ritchie dan Crouch (2005) nilai keunikan kesejarahan dari sebuah bangunan dengan arsitektur tradisional dapat dijadikan daya tarik wisata dengan nilai tambah berupa nilai sejarah.

\section{Kesimpulan}

Persepsi wisatawan terhadap Daya Tarik Wisata Jatiluwih sebagai bagian dari Warisan Budaya Dunia yang mencapai skor tertinggi adalah pengelolaan daya tarik wisata memberi kesempatan kerja bagi masyarakat, keramahan staf dalam memberikan pelayanan, serta kealamian dan keindahan pemandangan di sekitar daya tarik wisata. Persepsi wisatawan yang mencapai skor terendah adalah harga cinderamata terjangkau, fasilitas internet mudah diakses, tersedia cinderamata dengan ciri khas lokal, dan kelancaran lalu lintas di sekitar daya tarik wisata.

Wisatawan domestik dan mancanegara memberi apresiasi tertinggi terhadap kesempatan kerja bagi masyarakat dari pengelolaan daya tarik wisata. Dengan tingginya skor terhadap indikator ini, untuk pengelolaan daya tarik wisata yang berkelanjutan diperlukan upaya-upaya agar penyerapan tenaga kerja bagi masyarakat lokal dan pelibatan petani dalam kegiatan wisata ditingkatkan sehingga dapat memberikan kesejahteraan. Persepsi wisatawan yang baik terhadap keramahan staf dalam memberikan pelayanan perlu terus dipertahankan. Demikian juga dengan apresiasi wisatawan yang tinggi terhadap kealamian dan keindahan pemandangan di sekitar daya tarik wisata. Wisatawan mengagumi keberadaan daya tarik wisata yang merupakan bagian dari Warisan Budaya Dunia dan berharap agar eksistensinya tetap dijaga dan dilestarikan.

Selain persepsi wisatawan yang positif, indikator-indikator yang memperoleh penilaian yang kurang baik juga harus mendapatkan perhatian. Persepsi wisatawan yang kurang baik terhadap harga cinderamata, kemudahan dalam mengakses internet, ketersediaan cinderamata dengan ciri khas lokal, dan kelancaran lalu lintas di sekitar daya tarik wisata. Sebaiknya Manajemen Operasional Daya Tarik Jatiluwih melakukan koordinasi dan sinkronisasi dengan pemangku kepentingan yang terkait agar dapat dirumuskan solusi untuk mengatasinya, sehingga dapat memberikan kepuasan bagi wisatawan terhadap indikator-indikator tersebut.

Persepsi wisatawan memiliki peran penting dalam mengevaluasi pengelolaan daya tarik wisata. Berdasarkan indikator-indikator persepsi yang dapat memberikan kepuasan dan ketidakpuasan bagi wisatawan dapat dijadikan sebagai bahan evaluasi untuk pengelolaan daya tarik wisata yang 
berkelanjutan. Untuk itulah diperlukan upaya-upaya untuk mengurangi kesenjangan antara harapan dan persepsi. Seperti pernyataan Perera (2014) dan Khlaikaew (2015) untuk meningkatkan keberlanjutan warisan budaya sangatlah penting mengurangi kesenjangan antara harapan dan persepsi.

Pengkajian mengenai persepsi wisatawan tidak menganalisis mengenai kesenjangan antara ekspektasi dan persepsi dari wisatawan. Diperlukan penelitian lebih lanjut untuk menganalisis kesenjangan antara ekspektasi dan persepsi yang bermanfaat untuk mengembangkan strategi pemasaran daya tarik wisata.

\section{Daftar Pustaka}

Gee, C.Y dan Fayos-Sola, E. (1999). International Tourism: a Global Perspective. Madrid: WTO. Jaafar, R.E., Tambi, A.M.A., Sa'adin, I., dan Husain, A. (2014). Tourism, Leisure and Global Change. 1: 49-58.

Jafari. (2001). The Scientification of Tourism. dalam V. L. Smith and M. Brent. Host and Guests Revisited: Tourism Issues of The 21st Century. New York: Cognizant.

Khlaikaew, K. (2017). The Cutural Tourism Management under Context of World Heritage Sites: Stakeholders' Opinion between Luang Prabang Communities, Laos and Muang-Kao Communities, Shukotai Thailand. Procedia Economics and Finance. 23: 1286-1295. https://doi.org/10.1016/S2212-5671(15)00563-8.

Kierchhoff, H.W. (1997). Architecture and Tourism. Annals of Tourism Research. 24(1): 249-251.

Dzulkifli, M. dan Masjhoer, J. M. (2020). The Measurement of Tourist Satisfaction Levels on Attractions, Accessibility, and Amenities in Pulesari Tourism Village, Sleman Regency. Jurnal Pariwisata Terapan. 4(1): 48-58. https://doi.org/10.22146/jpt.51330

Perera, D.A.S., Chandran, V.G.R., Silva, D.A.C.S., dan Chinna, K. (2014). Tourist Expectation and Perception of World Heritage Site Sigiriya: Policy and Institutional Implications for Sri Lanka. Institution and Economics. 7(2): 165-183.

Parasuraman, A., Zeithaml, V. A., dan Berry, L. L. (1985). A Conceptual Model of Service Quality and Its Implications for Future Research. Journal of Marketing. 49: 41-50. https://doi.org/10.2307/1251430.

Ratman, D.R. (2016). Pembangunan Destinasi Prioritas 20116-2019. Makalah Rapat Koordinasi Nasional Kementerian Pariwisata. Jakarta

Ritchie, B.J., dan Crouch, G.I. (2005). The Competitive Destination: A Sustainable Tourism Perspective. Wallingford: CABI Publishing.

Sarwono, S.W. (2003). Teori-teori Psikologi Sosial. Jakarta: Raja Grafindo Persada.

Seyidov, J., dan Adomaitiene, R. (2016). Factors Influencing Local Tourists' Decision-Making on Choosing a Destination: A Case of Azerbaijan. Ekonomika. 95(3): 112-127. https://doi.org/10.15388/Ekon.2016.3.10332.

Slovin, M.J. (1960). Sampling. New York: Simon and Schuster Inc.

Teo, C.B.C., Mohd Khan, N.R., dan Abd Rahim, F.H. (2014). Understanding Cultural Heritage Visitor Behavior: The Case of Melaka as World Heritage City. Procedia-Social and Behavioral Sciences. 130: 1-10. https://doi.org/10. 1016/j.sbspro.2014.04.001. 
Vong, F. (2013). Relationships among Perception of Heritage Management, Satisfaction and Destination Cultural Image. Journal of Tourism and Cultural Change. 11(4): 287-301. https://doi.org/10.1080/14766825.2013.852564.

Wardana, I G.N.W. (2018). Buku Panduan Tri Hita Karana Awards \& Accreditation. Denpasar: Yayasan Tri Hita Karana Bali.

Wiranatha, A.S., dan Suryawardani. I G.A.O. (2016). Laporan Kajian Strategi Pemasaran Pariwisata Berbasis Subak di Bali (Studi di Daya Tarik Wisata Jatiluwih, Tabanan). Denpasar: Kementerian Pariwisata Republik Indonesia bekerjasama dengan Konsorsium Riset Pariwisata Universitas Udayana.

Yamashita, S. (2013). The Balinese Subak as World Cultural Heritages: In the Context of Tourism. Naskah Lengkap Kongres Kebudayaan Bali II. Denpasar. 